\title{
PERILAKU MENYONTEK MAHASISWA MUSLIM
}

\section{Warsiyah}

STIT Madina Sragen

Warsiyah0609@gmail.com

This study aimed to examine the effect of the direct and indirect simultaneously in a model pathway analysis. More specifically, this research examines (1) the effect of rate on Faith and Academic Procrastination Attitudes toward Cheating, (2) the direct or indirect effect of Level of Faith, Academic Procrastination and Attitudes toward Cheating on Cheating Behavior. Hypothesis testing was conducted based on data collected by questionnaire, which was composed specifically for this study, of 192 Muslim students studying in the Faculty of MT Walisongo IAIN Semarang, selected clusters. Hypothesis testing is done by using path analysis or path analysis. The results of path analysis showed empirically Faith rate has a direct negative effect while empirically Academic Procrastination has a significant positive direct effect on Attitude toward Cheating. However, the level of faith and Academic Procrastination and statistically or practically no direct influence on the attitude towards Cheating. Variable Level of Faith and Academic Procrastination indirectly (through attitude toward cheating) has a significant influence on Cheating Behavior. While the variable Attitude toward Cheatingdoes not have a direct or indirect effect on Cheating Behavior.

Keywords: Behavior cheat, attitudes toward cheating, academic procrastination, the level of faith. 


\section{A. Pendahuluan}

Menyontek merupakan bentuk kecurangan akademik yang membuat bias pelaksanaan evaluasi secara baik, karena hasil evaluasi tidak dapat menggambarkan ketercapaian kemampuan mahasiswa yang sebenarnya. Hasil evaluasi tersebut pula, menjadi landasan untuk mengambil keputusan salah satunya adalah untuk menentukan kelulusan mahasiswa selama mengikuti proses perkuliahan. Sehingga, mahasiswa harus menyiapkan diri dengan baik dalam menghadapai evaluasi.

Aktivitas menyontek dilakukan oleh sebagian mahasiswa, terutama terjadi pada saat menghadapi ujian akhir semester. Saat ini menyontek pada saat ujian sepertinya bukan hal yang tabu lagi bagi sebagian kalangan mahasiswa. Berbagai cara dan strategi, mulai dari yang sederhana hingga tercanggih, dilakukan untuk mendapatkan jawaban. Mulai dari bertanya pada teman, bahkan saling tukar lembar jawaban, hingga melihat catatan kecil di kertas atau di handphone yang telah dipersiapkan sebelumnya. ${ }^{1}$

Ketakutan akan kegagalan dan keinginan untuk mendapatkan nilai yang baik menjadi alasan bagi sebagian peserta didik mengambil jalan pintas, seperti menyontek. Menyontek tidak hanya dilakukan oleh individu pada tingkat Sekolah Dasar (SD) bahkan sampai tingkat Pascasarjana (S2 dan S3). ${ }^{2}$ Berbagai hasil penelitian yang dilakukan di berbagai perguruan tinggi, baik di dalam maupun di luar negeri, mengindikasikan bahwa aktivitas menyontek sudah menjadi budaya dan sekaligus "wabah" yang telah menyerang sebagian besar pelajar di dunia. Wabah menyontek yang diduga telah ada sejak tiga abad yang lalu ditemukan diberbagai belahan dunia. Penelitian McCabe, Trevino dan Butterfield pada tahun 2001 pada mahasiswa AS menemukan sekitar 90 persen dari seluruh mahasiwa telah melakukan kecurangan akademik yaitu menyontek, meskipun beberapa diantarannya hanya kadang-kadang dalam melakukannya. ${ }^{3}$

Perilaku menyontek merupakan salah satu indikasi kegagalan proses pendidikan dalam mencapai salah satu tujuan pendidikan yaitu membentuk peserta didik yang berakhlak mulia. Perilaku menyontek merupakan bentuk kecurangan akademik yang bukan hanya merugikan lembaga pendidikan dan pemerintah, tetapi juga merugikan peserta didik itu sendiri. Trisno Zuardi mengungkapkan bahwa perguruan tinggi memiliki peran penting dalam upaya pencegahan perilaku menyontek tersebut dalam rangka mewujudkan misinya untuk mencari, menemukan, mempertahankan, dan menjunjung tinggi kebenaran. Mahasiswa, dosen, peneliti, dan tenaga kependidikan yang berkarya di bidang akademik di perguruan tinggi bersangkutan, memiliki otonomi keilmuan dan kebebasan akademik. Dalam melaksanakan otonomi tersebut para civitas akademik wajib menjunjung tinggi kejujuran dan etika akademik, terutama larangan

1 Friyatmi, 2011, Faktor-faktor Penentu Perilaku Mencontek di Kalangan Mahasiswa, Fakultas Ekonomi UNP Vol 7, No 2 (2011): TINGKAP. Diakses pada 27 November 2012 dari http://ejournal.unp.ac.id/index. pdf. hlm. 174

2 Dody Hartanto, 2012, Bimbingan \& Konseling Menyontek: Mengungkap Akar Masalah dan Solusinya, Jakarta: Indeks, hlm. 2.

3 Jacob Eisenberg, 2004, To Cheat Or Not To Cheat: Effects OfMoral Perspective And Situational Variables On Students' Attitudes, Journal of Moral Education, Vol. 33, No. 2, June 2004 , University College Dublin, Ireland, hlm. 164. 
untuk melakukan plagiat dalam menghasilkan karya ilmiah, sehingga kreativitas dalam bidang akademik dapat tumbuh dan berkembang. ${ }^{4}$ Penelitian ini menfokuskan kajiannya pada perilaku menyontek mahasiswa, agar lebih bermakna variabel tersebut dikaitkan dengan faktorfaktor yang mempengaruhinya, khususnya tingkat keimanan dan prokrastinasi akademik, serta variabel yang mengantarainya, yakni variabel sikap terhadap menyontek.

\section{B. Kajian Teoritik}

\section{Perilaku Menyontek Mahasiswa}

Mencontek atau nyontek dalam bahasa Arab disebut ghish (الغش) dan khadirah (الخديعة) yang berarti tipu daya. Sedangkan dalam bahasa inggris kata menyontek sama artinya dengan cheat. Dalam KBBI disebutkan bahwa menyontek adalah mengutip tulisan sebagaimana aslinya. ${ }^{5}$ Secara istilah definisi menyontek sebagaimana menurut beberapa tokoh sebagaimana dikutip Dody Hartanto, di antaranya Ehrlich, Flexner, Carruth dan Hawkins dan juga Eric M. Andermen dan Tamera B. Murdock adalah melakukan ketidakjujuran dalam rangka meraih keuntungan. Dellington menyebutkan bahwa perilaku menyontek adalah bentuk usaha-usaha dalam mencapai keberhasilan melalui cara-cara yang curang atau tidak jujur. ${ }^{6}$

Athanasou dan Olasehinde menyebutkan tentang perilaku menyontek adalah kegiatan menggunakan bahan atau materi yang tidak diperkenankan atau menggunakan pendampingan dalam tugas-tugas akademik yang bisa memengaruhi hasil evaluasi atau penilaian. ${ }^{7}$ Berdasarkan beberapa pengertian tersebut, perilaku menyontek dalam penelitian ini adalah perbuatanperbutan yang dilakukan pada saat orang tersebut melakukan tes atau ujian atau pada saat membuat paper atau makalah bahkan tugas akhir (skripsi, tesis, desertasi) dengan cara yang tidak jujur dan tidak sesuai dengan aturan yang berlaku. Hal ini sama halnya perilaku menyontek merupakan perbuatan yang melanggar tata tertib atau kode etik lembaga pendidikan.

Sebagai sebuah bentuk perilaku, maka perilaku menyontek dapat diamati dan tidak terlepas dari beberapa dugaan adanya pengaruh lingkungan atau pengalaman yang terbentuk akibat interaksi yang dilakukan dengan lingkungannya. Pembentukan perilaku menyontek juga tidak terlepas adanya pengaruh-pengaruh baik dari intern maupun intern. Sehingga perilaku yang tidak diharapkan dapat berubah atau dipelajari kembali dengan cara yang sama.

\section{Faktor - Faktor Yang Mempengaruhi Perilaku Menyontek}

Faktor penting yang diduga menyebabkan mahasiswa melakukan tindakan menyontek yang berasal dari mahasiswa itu sendiri adalah berhubungan dengan kecenderungan mereka untuk menerima atau menolak sesuatu berdasarkan penilaiannya yang disebut dengan

4 Trisno Zuardi 2011, Pencegahan dan Penanggulangan Plagiat Di Perguruan Tinggi, Kementrian Pendidikan Nasional Biro Kepegawaian, hlm. 2

5 Departemen Pendidikan dan Kebudayaan, 2008, Kamus Besar Bahasa Indonesia, Jakarta: Balai pustaka, hlm. 1330

6 Dody Hartanto, 2012, Bimbingan \& Konseling Menyontek: Mengungkap Akar Masalah dan Solusinya, Jakarta: Indeks, hlm. 10

7 Dody Hartanto, 2012, Bimbingan \& Konseling Menyontek: Mengungkap Akar Masalah dan Solusinya, Jakarta: Indeks, hlm. 11 
sikap. Sikap positif atau negatif terhadap perilaku menyontek tersebut bervariasi antar individu sejalan dengan faktor yang memengaruhinya. Faktor-faktor tersebut berkenaan dengan bagaimana keimanan dalam diri individu mahasiswa dan perilaku prokrastinasi akademik atau menunda-nunda pekerjaan. Keragaman individu dalam faktor-faktor tersebut mendorong terjadinya variasi sikap mereka terhadap perilaku menyontek. Untuk mengetahui bagaimana masing-masing faktor tersebut memengaruhi sikap terhadap perilaku menyontek, pada bagian berikut akan dibahas secara konseptual masing-masing faktor tersebut.

a. Sikap terhadap Menyontek

Sikap merupakan bagian penting dalam kehidupan sosial manusia, karena dapat menentukan perilaku seseorang dalam berinteraksi dengan orang lain. ${ }^{8}$ Louis Thurstone tahun 1928, Rensis Likert tahun 1932 dan Charles Osgood, mendefinisikan sikap sebagai suatu bentuk evaluasi atau reaksi perasaan. Sikap seseorang terhadap suatu objek adalah perasaan yang mendukung atau memihak (favorable) maupun perasaan tidak mendukung atau memihak (unfavorable) pada objek tersebut. ${ }^{9}$ Thurstone memandang sikap sebagai kecenderungan untuk mendukung atau menolak, mengevaluasi, suka atau tidak suka serta suatu tingkatan afeksi baik positif maupun negatif dalam hubungannya dengan objek-objek psikologis. ${ }^{10}$ Berdasarkan semua pengertian yang telah dipaparkan dapat dikatakan bahwa sikap adalah penilaian positif atau negatif terhadap isu, ide, orang, kelompok sosial, benda dan lain sebagainya.

Sikap memiliki ciri utama yaitu dua arah hubungan (positif dan negatif), memiliki karakteristik sebagai reaksi terhadap suatu objek yang merupakan hasil belajar dan interaksi sosial bukan pembawaan sejak lahir. Fishbein mendefinisikan sikap sebagai kecenderungan yang merupakan hasil belajar untuk merespons secara konsisten mendukung atau tidak mendukung terhadap suatu objek. ${ }^{11}$ Sikap mahasiswa terhadap perilaku menyontek didefinisikan sebagai suatu kecenderungan berdasarkan proses evaluasi dalam diri individu untuk memberikan kesimpulan dalam bentuk nilai baik-buruk, positif-negatif secara konsisten terhadap perilaku menyontek.

Sikap antara satu orang dengan orang lain terhadap satu objek yang sama dapat berbedabeda atau bervariasi. Hal ini juga karena tergantung dari perbedaan terbentuknya sikap itu sendiri dan kuatnya stimulus serta evaluasi dalam diri individu terhadap suatu objek sikap. Dengan demikian sikap terhadap menyontek dalam penelitian ini juga dapat bervariasi, tergantung pada stimulus yang diterima mahasiswa serta evaluasi dalam diri mahasiswa terhadap perilaku menyontek.

8 Daniel J. Mueller, 1986, Measuring Social Attitudes: A Handbook for Researchers and Practitioners, New York: Teachers College Press, hlm. 7

9 Saifuddin Azwar, 2007, Sikap Manusia, Yogyakarta: Pustaka Pelajar, hlm. 4-5

10 Mueller, Daniel J., 1986, Measuring Social Attitudes: A Handbook for Researchers and Practitioners, New York: Teachers College Press, hlm. 3

11 Fishbein, M., \& Ajzen, I., 1975, Belief, Attitude, Intention, and Behavior: An Introduction to Theory and Research, Reading, MA: Addison-Wesley, hlm. 6 
Sikap berkaitan dengan keyakinan atas informasi dan perasaan hasil evaluasi, maka keyakinan tersebut dapat berubah karena adanya berbagai faktor yang memengaruhinya. Faktor-faktor yang diduga dapat memengaruhi sikap terhadap menyontek diantaranya adalah keyakinan atau pandangan individu tentang agamanya yang diantara ajaranya adalah melarang perbuatan yang menyimpang termasuk menyontek. keyakinan tersebut akan terefleksikan pada bagaimana seseorang bersikap dan memandang agamanya. Selain itu karena sikap terhadap menyontek dalam pendidikan berhubungan dengan proses belajar oleh individu tersebut maka, sikap juga akan dipengaruhi oleh perilaku prokrastinasi atau perilaku menunda-nunda dalam belajar dan mengerjakan tugas. Dengan kata lain sikap terhadap menyontek akan dipengaruhi oleh tingkat keimanan dan prokrastinasi akademik. Karena itu variasi kedua faktor tersebut juga akan terefleksikan pada variasi sikap terhadap menyontek.

b. Prokrastinasi Akademik

Procrastination adalah bahasa latin yang tediri atas kata pro yang berarti mendorong maju atau bergerak maju dan akhiran crastinus adalah keputusan hari esok. Sehingga bermakna menangguhkan atau menunda sampai hari berikutnya. Prokrastinasi yang berkaitan dengan akademik adalah kecenderungan untuk menunda-nunda penyelesaian tugas atau pekerjaan akademik $^{12}$.

Milgram menyebutkan bahwa prokrastinasi dilakukan semata-mata untuk melengkapi tugas secara optimal. Namun penundaan itu tidak membuat tugas lebih baik, hal itu mengarah pada penundaan yang tidak berguna. ${ }^{13}$ Definisi perilaku prokrastinasi sebagaimana diungkapkan Millgram tersebut mengindikasikan bahwa perilaku prokrastinasi akademik kaitannya dalam penelitian ini merupakan penundaan yang dilakukan oleh seorang mahasiswa di dalam menyelesaikan tugas-tugas akademik dari kampusnya baik karena alasan sesuatu ataupun karena malas mengerjakannya.

Dalam perspektif Islam perilaku prorastinasi akademik juga dilarang, Allah SWT senantiasa menuntut kepada seluruh manusia agar selalu memanfaatkan waktu semaksimal mungkin dan mengisinya dengan berbagai amal atau perbuatan-perbuatan yang positif, bukannya menunda-nunda pekerjaan atau tugas yang seharusnya bisa dikerjakan sekarang tapi ditunda-tunda dengan atau tanpa alasan.

Perbedaan faktor yang memengaruhi prokrastinasi akademik, mengindikasikan bahwa terdapat perbedaan tingkat prokrastinasi akademik dikalangan mahasiswa. Dengan demikian kita bisa mengakatakan bahwa mahasiswa lebih tinggi tingkat prokrastinasi akademik daripada mahasiswa yang lain. Keragaman tingkat prokrastinasi pada individu juga akan memberikan pengaruh bervariasinya dampak yang dialami oleh individu tersebut, terutama kaitanya dengan proses belajar yang sedang ditempuh. Kaitannya dengan belajar maka dampaknya salah satunya adalah sikap terhadap menyontek.

12 Nur Ghufron dan Rini Risnawita, 2011, Teori-Teori Psikologi, Jogjakarta: Ar-Ruzz Media, hlm. 149-151

13 Rumiani, 2006, Prokrastinasi Akademik Ditinjau Dari Motivasi Berprestasi dan Stres Mahasiswa, Jurnal Psikologi Universitas Diponegoro Vol.3 No. 2, Desember 2006, hlm. 38 
Bagaimana perilaku prokrastinasi bisa memengaruhi sikap terhadap menyontek? Menurut Ferrari, dkk. sebagaimana dikutip Ghufron, bahwa prokrastinasi akademik banyak berakibat negatif, dengan melakukan penundaan, banyak waktu yang terbuang dengan sia-sia. Tugastugas menjadi terbengkalai, bahkan bila diselesaikan hasilnya menjadi tidak maksimal. ${ }^{14}$ Kondisi seperti ini dapat menciptakan peluang bagi individu untuk melakukan tindakan menyontek sebagai jalan pintas agar tugas-tugasnya dapat terselesaikan. Keberanian untuk mengambil tindakan menyontek ini tidak terlepas dari sikapnya terhadap menyontek. sikap terhadap menyontek terbentuk berdasarkan informasi yang diterima mengenai menyontek, jika informainya positif, hasil evaluasi afektifnya akan menerima dan menganggap biasa perilaku menyontek sehingga sikapnya positif. Sebaliknya jika informasi yang diterimanya negatif, hasil evaluasi afektifnya akan menolak atau mengaggap perilaku menyontek adalah perbuatan yang dilarang maka sikapnya menjadi negatif. Sikap terhadap menyontek tersebut beragama karena perbedaan tingkat prokrastinasi akademiknya akibat dari dampak negatif yang ditimbulkan karena menunda-nunda pekerjaan.

c. Keimanan

Keimanan merupakan salah satu dimensi yang paling esensial dalam beragama, hal ini karena dalam beragama orang mutlak harus memiliki keyakinan atau keimanan. secara bahasa keimanan berasal dari kata dasar iman atau disebut juga akidah merupakan pokok dasar dari ajaran Islam yang sering disebut dengan akidah Islamiyah. ${ }^{15}$ Secara etimologi, kata iman merupakan kata kerja dari mashdar al-amm yang berarti keamanan, mengandung arti ketentraman dan kedamaian kalbu dan dari kata itu juga muncul sifat amanah dapat dipercaya (al-amanah). Seorang dikatakan al-amin (dapat dipercaya) jika hatinya tentram karena perilakunya baik dan tidak dikhawatirkan akan berkhianat. Iman merupakan dasar pemikiran bagi perjalanan dan kehidupan praktis manusia. ${ }^{16}$

Sedangkan secara terminologi sebagaimana disebutkan Al Wazat bahwa iman yang benar adalah akidah yang tidak dicampuri keraguan dan amal yang membenarkan akidah. ${ }^{17}$ Keimanan atau keyakinan merupakan salah satu dari dimensi keberagamaan, keimanan atau disebut juga dimensi ideologi. Dimensi ideologi adalah keterbukaan seseorang untuk menerima yang dogmatik dalam agamanya atau mengakui kebenaran doktrin-doktrin agamanya. ${ }^{18}$ Ideologis dapat diartikan sebagai ilmu pengetahuan yang berisi tentang ide-ide agama atau doktrin atau kepercayaan. Ide sentral dalam agama Islam adalah rukun iman itu merupakan pokok keyakinan umat Islam. Rukun Islam merupakan konsep bersistem yang dijadikan azas pendapat yang

14 Ghufron, M. N., 2003. Hubungan Kontrol Diri dan Persepsi Remaja terhadap Penerapan Disiplin Orang Tua dengan Prokrastinasi Akademik, Thesis. Jogjakarta: Program Pasca Sarjana Universitas Gadjah Mada Yogyakarta. Diakases 11 Januari 2013 dari (http://www.damandiri.or.id/file/mnurgufronugmbab2.pdf), hlm. 17

15 Masjfuk Zuhdi, 1988, Studi Islam Jilid I: Akidah, Jakarta: Rajawali, hlm. 60

16 Abul A'la Maududi, 1975, Prinsip-prinsip Islam (Principles of Islam), Terj. Abdullah Suhalili, Bandung: AlMa'arif, hlm. 3

17 Abdullah Al-Wazat \& Ahmad Salamah, dkk. 1994, Pokok-Pokok Keimanan, Tarmana Ahmad Qasim, Bandung: Trigenda Karya, hlm. 22

18 Ancok, Djamaluddin dan Fuad Nashori Suroso, 1994, Psikologi Islam, Yogyakarta: Pustaka Pelajar, hlm. 77 
memberikan arah dan tujuan untuk kelangsungan hidup beragama.Kesulitan untuk mengungkap keyakinan seseorang sudah diakui oleh para ilmuwan agama, namun para ahli bidang psikologi menemukan metode untuk mengungkap keberagamaan seseorang sebagaimana pendapat Zakiah Daradjat bahwa unsur perasaan alam kesadaran agama yaitu perasaan yang membawa pada keyakinan yang dihasilkan oleh tindakan (amaliyah). ${ }^{19}$ Maka dapat dipahami bahwa wujud kepercayaan dari rukun iman itu akan nampak dalam tindakan. Hal ini merupakan realisasi iman dalam kehidupan.

Bagaimana keimanan bisa memengaruhi sikap terhadap menyontek? Menurut Sayid Sabiq Iman dan akidah yang mantap dalam jiwa seseorang akan mengangkat ke tingkat moral yang luhur, sehingga menjauhkannya dari sifat-sifat materialistis, egoistis, dan lain-lain yang bersumber pada pengagungan yang berlebihan kepada kebendaan dan keduniawian termasuk salah satunya adalah berbuat curang seperti menyontek. ${ }^{20}$ Mereka akan meyakini bahwa ajaran Islam merupakan ajaran yang kebenaran tidak diragukan lagi. Hal ini akan memengaruhi komponen keyakinan sikapnya terhadap menyontek, yang selanjutnya memengaruhi afeksinya. Sikap terhadap menyontek terbentuk berdasarkan informasi yang diterima mengenai perilaku menyontek, jika informainya positif, hasil evaluasi afektifnya akan menerima dan menganggap biasa perilaku menyontek sehingga sikapnya positif. Sebaliknya jika informasi yang diterimanya negatif, hasil evaluasi afektifnya akan menolak atau mengaggap perilaku menyontek adalah perbuatan yang dilarang maka sikapnya menjadi negatif. Perbedaan sikap tersebut selanjutnya akan mendorong terjadinya perbedaan dalam perilaku menyontek dikalangan mahasiswa. Dengan demikian bervariasinya tingkat keimanan di antara mahasiswa secara konsisten akan terefleksikan dalam bervariasinya sikap mereka terhadap menyontek dan perilaku menyonteknya.

\section{Kerangka Berfikir Dan Hipotesis Penelitian}

Fokus permasalahan penelitian ini adalah perilaku menyontek yang dilakukan oleh mahasiswa. Dalam rangka menggambarkan bagaimana variabel ini bervariasi atar subyek penelitian sebagai konsekuensi dari variasi dalam variabel independen (tingkat keimanana dan prokrastinasi akademik) dan variabel antara (sikap terhadap menyontek) dapat dijelaskan dalam suatu konstalasi yang berupa path diagram sebagai berikut:

Gambar 1. Model Teoretis Perilaku Menyontek Mahasiswa

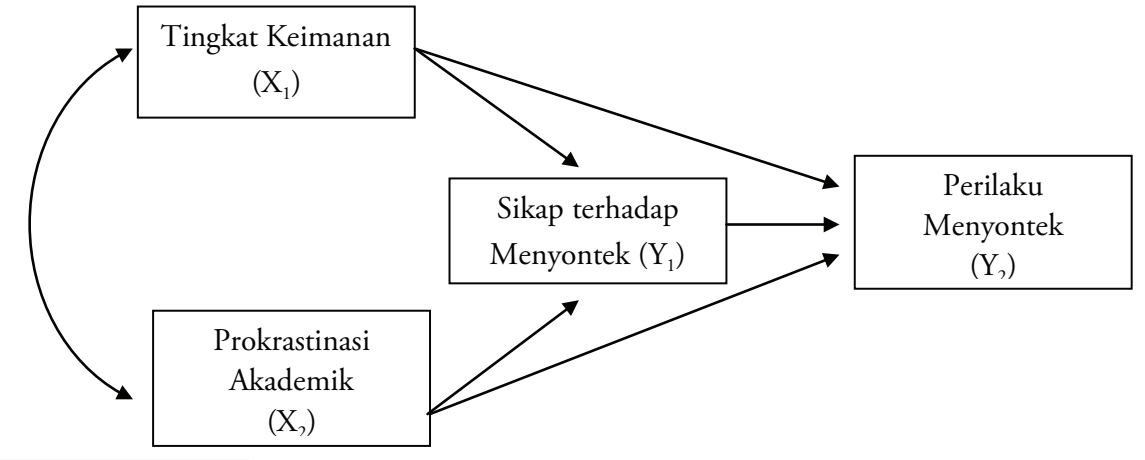

19 Zakiyah Daradjat, 1993, Ilmu Jiwa Agama, Jakarta: Bulan Bintang, hlm. 4 20 Sayid Sabiq, tt, Inilah Islam, Semarang: CV. Toha Putra, hlm. 36 
Berdasarkan teori, hasil-hasil penelitian yang terkait, dan kerangka berpikir sebagaimana dibahas sebelumnya dapat dirumuskan hipotesis penelitian yang secara konseptual diorganisasikan berdasarkan masing-masing variabel endogenus atau dependen sebagai berikut:

1) Pengaruh Tingkat Keimanan $\left(X_{1}\right)$ dan Prokrastinasi Akademik $\left(X_{2}\right)$ pada Sikap terhadap Menyontek $\left(\mathrm{Y}_{1}\right)$

2) Pengaruh Tingkat Keimanan $\left(X_{1}\right)$, Prokrastinasi Akademik $\left(X_{2}\right)$ dan Sikap terhadap Menyontek $\left(\mathrm{Y}_{1}\right)$ pada Perilaku Menyontek $\left(\mathrm{Y}_{1}\right)$.

\section{Metodologi}

1. Subyek

Penelitian ini melibatkan 197 orang mahasiswa yang belajar di Fakultas Tarbiyah IAIN Walisongo Semarang. Mereka dipilih secara klaster berdasarkan Program Studi dan kelas. Dari langkah ini terpilih Jurusan PAI, KI dan PGMI, mewakili kelompok non eksakta (sosial dan humaniora), dan Jurusan Tadris Kimia dan Tadris Matematika, mewakili kelompok eksakta (sain dan teknologi).

\section{Variabel dan Instrumen}

Penelitian ini melibatkan dua variabel eksogen (Tingkat Keimanan, dan Prokrastinasi Akademik) dan dua variabel endogen (Perilaku Menyontek, Sikap terhadap Menyontek). Pengembangan instrumen dilakukan sesuai dengan karakteristik masing-masing variabel dan dimensinya. Instrumen awal diujicobakan pada 62 subyek dari populasi yang sama dengan penelitian utama, yang hasilnya digunakan untuk kalibrasi validitas butir dan reliabilitas instrumen masing-masing variabel atau dimensi. Secara ringkas, pengukuran masing-masing variabel tersebut adalah sebagai berikut:

a. Perilaku Menyontek

Instrumen perilaku menyontek disusun dalam skala dengan menggunakan model skala intensitas, yang menunjukan tingkat keseringan dalam melakukan tindakan menyontek. Instrumen terdiri atas 24 yang diseleksi dari 25 butir pertanyaan berdasarkan validasi dari hasil ujicoba instrumen variabel tersebut. Setiap butir instrumen disusun dalam bentuk pernyataan positif (menunjukan perilaku menyontek) dan pernyataan negatif (menyatakan tidak menyontek) tentang indikator perilaku menyontek. Dalam merespon pernyataan tersebut, responden diminta memilih salah satu dari lima alternatif jawaban: Selalu (SL), Sering (SR), Kadang-kadang (KD), Jarang (JR) dan Tidak Pernah (TP) yang paling sesuai dengan kenyataan dan penilaian tentang diri mereka. Analisis reliabilitas dengan alpha Cronbach $^{21}$ untuk menghasilkan nilai a terhadap butir - butir yang valid dan menghasilkan nilai $\alpha=0,764$.

b. Sikap terhadap Menyontek

Sikap terhadap menyontek adalah suatu kecenderungan berdasarkan proses evaluasi dalam diri individu untuk memberikan kesimpulan dalam bentuk nilai baik-buruk, positif- 
negatif secara konsisten terhadap perilaku menyontek. Instrumen sikap terhadap menyontek disusun dalam skala dengan menggunakan model summated-rating scale yang terdiri dari 16 yang diseleksi dari 25 butir pertanyaan. Setiap butir instrumen disusun dalam bentuk pernyataan positif (menunjukan dukungan yang kuat) dan pernyataan negatif (menyatakan tidak memberikan dukungan yang sangat kuat) tentang obyek yang berkenaan dengan perilaku menyontek. Dalam merespon pernyataan tersebut, responden diminta memilih salah satu dari empat alternatif jawaban: Sangat Setuju, Setuju, Tidak Setuju dan Sangat Tidak Setuju yang paling sesuai dengan kenyataan dan penilaian mereka. Instrumen terdiri dari 16 butir yang diseleksi dari 25 butir instrumen awal dengan tingkat reliabilitas Cronbach alpha: $\alpha=0,75$.

c. Prokrastinasi Akademik

Prokrastinasi akademik diartikan sebagai kebiasaan menunda-nunda dalam menyelesaikan tugas-tugas akademiknya dan lebih suka melakukan hal yang menyenangkan dibandingkan harus mengerjkan tugas-tugasnya. Instrumen prokrastinasi akademik disusun dalam skala dengan menggunakan model summated-rating scale. Setiap butir instrumen disusun dalam bentuk pernyataan positif (menunjukan melakukan prokrastinasi) dan pernyataan negatif (menyatakan tidak melakukan prokrastinasi). Dalam merespon pernyataan tersebut, responden diminta memilih salah satu dari lima alternatif jawaban: Selalu (SL), Sering (SR), Kadang-kadang (KD), Jarang (JR) dan Tidak Pernah (TP) yang paling sesuai dengan kenyataan dan penilaian mereka. Instrumen terdiri dari 17 butir yang diseleksi dari 25 butir instrumen awal dengan tingkat reliabilitas Cronbach alpha: $\alpha=0,685$.

d. Keimanan

Keimanan merupakan keteguhan seseorang untuk menerima ajaran dogmatik dalam agamanya atau meyakini, mengakui kebenaran doktrin-doktrin agama Islam. Instrumen tingkat keimanan disusun dalam skala dengan menggunakan model summated-rating scale. Setiap butir instrumen disusun dalam bentuk pernyataan positif (menunjukan keyakinan yang kuat) dan pernyataan negatif (menyatakan keyakinan yang rendah). Dalam merespon pernyataan tersebut, responden diminta memilih salah satu dari lima alternatif jawaban: Sangat Yakin (SY), Yakin (Y), Kadang-kadang (KD), Tidak Yakin (TY) dan Sangat Tidak Yakin (STY) yang paling sesuai dengan kenyataan dan penilaian mereka. Instrumen terdiri dari 18 butir yang diseleksi dari 25 butir instrumen awal dengan tingkat reliabilitas Cronbach alpha: $\alpha=0,772$.

3. Analisis Data

Untuk menguji hipotesis, data dianalisis dengan menggunakan teknik analisis jalur atau path analysis untuk menguji hubungan antar variabel dalam suatu model linier. Langkah analisis jalur ini dilakukan dengan menggunakan analisis regresi ganda untuk menghasilkan koefisien regresi baku (standardized regression coefficient [beta weight]), ß. Koefisien ini menunjukkan besarnya pengaruh, path coefficient, $p$, variabel independen pada variabel dependen. ${ }^{22}$ Pengaruh 
variabel independen pada dependen dinyatakan signifikan bila $p \geq 0,05$. Dengan analisis ini dapat diungkap pengaruh langsung masing-masing variabel independen pada masing variabel dependennya. Di samping itu, juga dilakukan dekomposisi untuk mengetahui komponen dari besaran koefisien korelasi antara variabel independen dan dependen. ${ }^{23}$

\section{E. Hasil Dan Pembahasan}

\section{Hasil}

Dalam rangka menguji hipotesis, data dianalisis dalam dua tahapan regresi. Karena merupakan satu rangakaian, hasil analisis tersebut selanjutnya disatukan dalam suatu model analisis jalur atau path analisis. Rangkuman hasil secara singkat disajikan dalam tabel dan diagram jalur di halaman berikut ini.

Tabel 1. Koefisien jalur $(p)$ variabel independen terhadap variabel dependen

\begin{tabular}{|c|l|c|c|c|c|l|}
\hline No. & \multicolumn{1}{|c|}{ Hubungan antar variabel } & Lambang & Koef. $p$ & $\mathrm{~T}$ & Prob. & Kesimpulan \\
\hline 1. & $\begin{array}{l}\text { Tingkat Keimanan dengan Sikap } \\
\text { terhadap Menyontek }\end{array}$ & $\mathrm{P}_{\mathrm{Y} 1 \mathrm{X} 1}$ & $-0,130$ & $-1,778$ & 0,077 & $\begin{array}{l}\text { Tidak } \\
\text { Signifikan }\end{array}$ \\
\hline 2. & $\begin{array}{l}\text { Prokrastinasi Akademik dengan Sikap } \\
\text { terhadap Menyontek }\end{array}$ & $\mathrm{P}_{\mathrm{Y} 1 \times 2}$ & $-0,044$ & $-0,609$ & 0,543 & $\begin{array}{l}\text { Tidak } \\
\text { Signifikan }\end{array}$ \\
\hline 3. & $\begin{array}{l}\text { Tingkat Keimanan dengan Perilaku } \\
\text { Menyontek }\end{array}$ & $\mathrm{P}_{\mathrm{Y} 2 \times 1}$ & 0,081 & 1,188 & 0,236 & $\begin{array}{l}\text { Tidak } \\
\text { Signifikan }\end{array}$ \\
\hline 4. & $\begin{array}{l}\text { Prokrastinasi Akademik dengan Perilaku } \\
\text { Menyontek }\end{array}$ & $\mathrm{P}_{\mathrm{Y} 2 \times 2}$ & 0,102 & 1,512 & 0,123 & $\begin{array}{l}\text { Tidak } \\
\text { Signifikan }\end{array}$ \\
\hline 5. & $\begin{array}{l}\text { Sikap terhadap Menyontek dengan } \\
\text { Perilaku Menyontek }\end{array}$ & $\mathrm{P}_{\mathrm{Y} Y \mathrm{Y} 1}$ & $-0,370$ & $-5,503$ & 0,000 & Signifikan \\
\hline
\end{tabular}

Gambar 2. Diagram jalur dan koefisien jalur variabel dependen dari variabel independennya

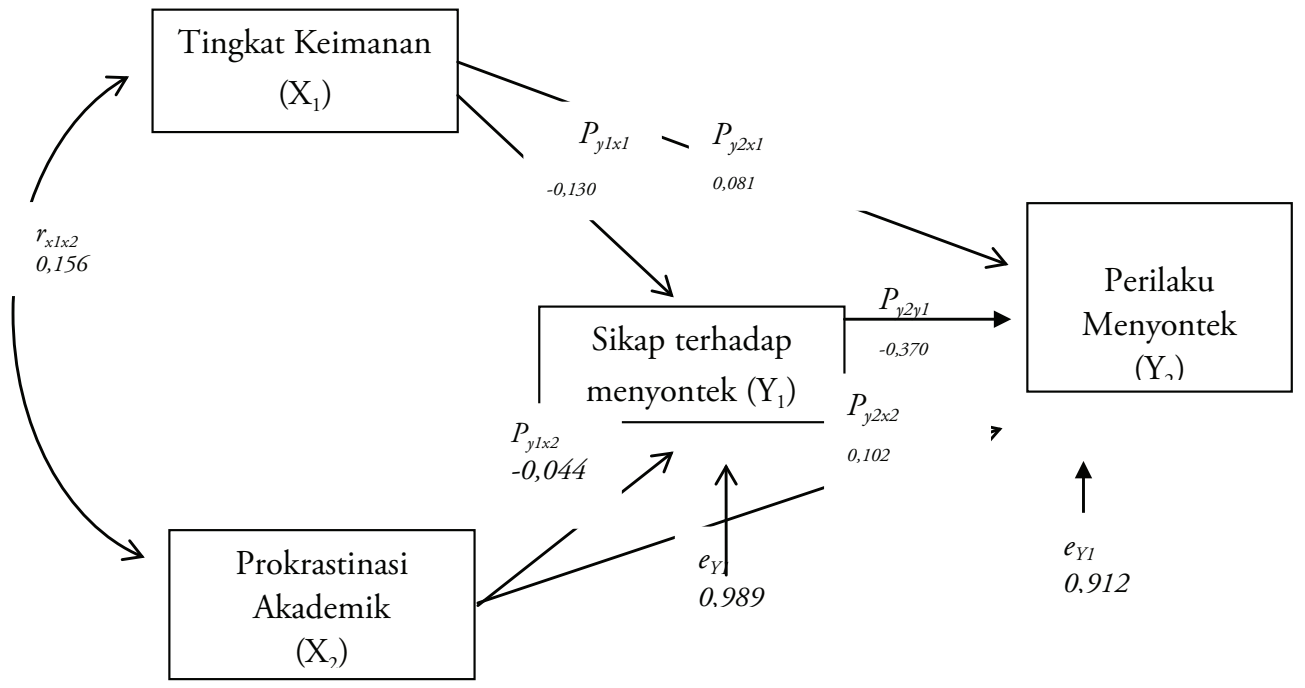

CBS College, hlm. 577-630

23 Elazar P. Pedhazur, 1982, Multiple Regression in Behavioral Research: Explanation and Prediction, New York: CBS College, hlm. 589 
Diagram di atas memperlihatkan arah pengaruh masing-masing variabel independen secra langsung maupun tidak langsung terhadap variabel dependennya. Secara rinci dapat dijelaskan sebagai berikut:

Pengaruh Tingkat Keimanan $\left(\mathrm{X}_{1}\right)$ dan Prokrastinasi Akademik $\left(\mathrm{X}_{2}\right)$ pada Sikap terhadap Menyontek $\left(\mathrm{Y}_{1}\right)$.

Pengaruh Tingkat Keimanan $\left(\mathrm{X}_{1}\right)$ pada Sikap terhadap Menyontek $\left(\mathrm{Y}_{1}\right)$ tidak signifikan, dengan nilai koefisien jalur $p_{\mathrm{Y} 1 X 1}=-0,130$, dengan nilai $\mathrm{t}=-1,778$ dan taraf signifikansi $p=0,077$. Hasil tersebut menunjukkan bahwa Tingkat Keimanan yang dimiliki oleh subjek (mahasiswa Fakultas Tarbiyah) tidak secara konsisten diikuti oleh variansi Sikap terhadap Menyontek. Tabel 2 tersebut juga menunjukan bahwa pengaruh Prokrastinasi Akademik $\left(\mathrm{X}_{2}\right)$ pada Sikap terhadap Menyontek $\left(\mathrm{Y}_{1}\right)$ juga tidak signifikan, dengan nilai koefisien jalur $p_{\mathrm{Y} 1 \mathrm{X} 2}=-0,044$, dengan nilai $\mathrm{t}=$ $-0,609$ dan taraf signifikansi $p=0,543$. Hasil tersebut menunjukkan bahwa Tingkat Prokrastinasi Akademik yang dimiliki oleh subjek (mahasiswa Fakultas Tarbiyah) tidak secara konsisten diikuti oleh variansi Sikap terhadap Menyontek. Tidak berbeda dengan Tingkat Keimanan, Pola hubungan antara Prokrastinasi Akademik $\left(\mathrm{X}_{2}\right)$ dengan Sikap terhadap Menyontek $\left(\mathrm{Y}_{1}\right)$ secara ringkas disajikan sebagai berikut: $r_{x 2 y 1}=p_{y 1 \times 2}+r_{x 1 \times 2} p_{y 1 \times 1}$. Sesuai dengan hasil analisis jalur dan korelasi antar variabel pengaruh masing-masing komponen kausal adalah: $\mathrm{DE}=p_{\mathrm{y} 1 \times 2}$ tidak signifikan Prokrastinasi Akademik $\left(\mathrm{X}_{2}\right)$ tidak memiliki hubungan langsung atau direct effect $(\mathrm{DE})=p_{\mathrm{y} 1 \mathrm{x} 1}$ yang signifikan dengan Sikap terhadap Menyontek $\left(\mathrm{Y}_{1}\right)$. Dengan demikian, Hipotesis penelitian $1\left(\mathrm{H}_{1}\right)$ yang menyatakan: "Ada pengaruh yang negatif dan signifikan Tingkat Keimanan $\left(\mathrm{X}_{1}\right)$ pada Sikap terhadap Menyontek $\left(\mathrm{Y}_{1}\right)$ ” tidak dapat diterima. Hal ini karena pengaruh langsung Tingkat Keimanan pada Sikap terhadap Menyontek tidak signifikan. Hipotesis penelitian $2\left(\mathrm{H}_{2}\right)$ yang menyatakan: "Ada pengaruh yang positif dan signifikan Prokrastinasi Akademik $\left(\mathrm{X}_{2}\right)$ pada Sikap terhadap Menyontek $\left(\mathrm{Y}_{1}\right)$ ” tidak dapat diterima. Hal ini karena pengaruh langsung Prokrastinasi Akademik pada Sikap terhadap Menyontek tidak signifikan.

Pengaruh Tingkat Keimanan (X1), Prokrastinasi Akademik (X2), dan Sikap terhadap Menyontek (Y1) pada Perilaku Menyontek (Y2).

Pengaruh Tingkat Keimanan $\left(\mathrm{X}_{1}\right)$ pada Perilaku Menyontek (Y2) sama seperti diatas tidak signifikan, dengan nilai koefisien jalur $=p_{\mathrm{y} 2 \mathrm{x} 1}=0,081$ dan taraf signifikansi $p=0,236$. Hasil ini menunjukkan bahwa variasi Tingkat Keimanan yang dimiliki oleh subjek (mahasiswa) tidak secara konsisten diikuti oleh variasi Perilaku Menyontek. Tidak berbeda dari Tingkat Keimanan, pengaruh Prokrastinasi Akademik $\left(\mathrm{X}_{2}\right)$ pada Perilaku Menyontek $\left(\mathrm{Y}_{2}\right)$ juga tidak signifikan. Koefisien jalur Perilaku Menyontek $\left(\mathrm{Y}_{2}\right)$ dari Prokrastinasi Akademik $\left(\mathrm{X}_{2}\right)$ adalah $p_{y 2 \times 2}=0,102$ dan $p=0,132$. Hal ini berarti bahwa variasi Perilaku Menyontek yang dimiliki oleh mahasiswa Muslim tidak secara konsisten diikuti dengan variasi Prokrastinasi Akademik mereka.

Berbeda dengan Tingkat Keimanan dan Prokrastinasi Akademik, Sikap terhadap Menyontek $\left(Y_{1}\right)$ berpengaruh negatif yang signifikan pada Sikap terhadap Menyontek $\left(\mathrm{Y}_{2}\right)$. Pengaruh 
tersebut ditunjukkan oleh nilai koefisien jalur dari $Y_{2}$ ke $Y_{1}$ dan taraf signifikansinya, yaitu = $p_{y 2 y l}=-0,370$ dan $p<0,001$. Hasil analisis ini menunjukkan bahwa semakin negatif Sikapnya terhadap Menyontek, semakin banyak intensitas Perilaku Menyonteknya.

Hasil dekomposisi hubungan antara masing-masing variabel independen dengan variabel dependen tersebut di atas secara ringkas dapat disajikan dalam tabel dekomposisi berikut ini.

Tabel 4. Dekomposisi hubungan kausal terhadap

Perilaku Menyontek $\left(\mathrm{Y}_{2}\right)$

\begin{tabular}{|c|l|c|c|c|}
\hline NO. & \multicolumn{1}{|c|}{ DARI VARIABEL } & DE & IE & TOTAL \\
\hline 1. & Tingkat Keimanan $\left(\mathrm{X}_{1}\right)$ & - & 0,048 & 0,048 \\
\hline 2. & Prokrastinasi Akademik $\left(\mathrm{X}_{2}\right)$ & - & 0,016 & 0,016 \\
\hline 3. & Sikap terhadap Menyontek $\left(\mathrm{Y}_{1}\right)$ & $-0,370$ & - & $-0,370$ \\
\hline
\end{tabular}

Sedangkan proporsi atau sumbangan efektif variabel independen $\left(\mathrm{X}_{1}, \mathrm{X}_{2}\right.$, dan $\left.\mathrm{Y}_{1}\right)$ pada Sikap terhadap Menyontek $\left(\mathrm{Y}_{2}\right)$ adalah sebagai berikut:

Tabel 5. Sumbangan efektif Variabel independen pada varian Perilaku Menyontek Menyontek $\left(\mathrm{Y}_{2}\right)$

\begin{tabular}{|c|l|c|c|c|}
\hline NO. & \multicolumn{1}{|c|}{ DARI VARIABEL } & DE & IE & TOTAL \\
\hline 1. & Tingkat Keimanan $\left(\mathrm{X}_{1}\right)$ & - & $\begin{array}{c}0,048(0,147) \\
=0,007\end{array}$ & 0,007 \\
\hline 2. & Prokrastinasi Akademik $\left(\mathrm{Y}_{2}\right)$ & - & $\begin{array}{c}0,016(0,138) \\
=0,002\end{array}$ & 0,002 \\
\hline $3,$. & Sikap terhadap Menyontek $\left(\mathrm{Y}_{1}\right)$ & $\begin{array}{c}-0,370(-0,387) \\
=0,143\end{array}$ & - & 0,143 \\
\hline \multicolumn{2}{r|}{ Jumlah Gabungan } & 0,143 & 0,009 & 0,152 \\
\hline
\end{tabular}

Tabel tersebut di atas memperlihatkan bahwa sumbangan efektif seluruh variabel independen pada Perilaku Menyontek $\left(\mathrm{Y}_{2}\right)$ adalah 15, 2 persen. Hampir semua proporsi variasi Perilaku Menyontek $\left(\mathrm{Y}_{2}\right)$ tersebut disumbangkan oleh variasi variabel Sikap terhadap Menyontek $\left(\mathrm{Y}_{1}\right)$, yang menyumbangkan 14,3 persen. Sedangkan proporsi yang dapat dijelaskan atau diprediksi oleh Tingkat Keimanan $\left(\mathrm{X}_{1}\right)$ dan Prokrastinasi Akademik $\left(\mathrm{X}_{2}\right)$ hanya 0, 9 persen. Dengan demikian, berdasarkan hasil-hasil analisis tersebut di atas dapat disimpulkan sebagai berikut:

Hipotesis penelitian $3\left(\mathrm{H}_{3}\right)$ yang menyatakan: "Ada pengaruh yang negatif dan signifikan Tingkat Keimanan $\left(\mathrm{X}_{1}\right)$ terhadap Perilaku Menyontek $\left(\mathrm{Y}_{2}\right)$, baik secara langsung maupun tidak langsung (melalui Sikap terhadap Menyontek $\left[\mathrm{Y}_{1}\right]$ )" tidak bisa diterima. Hal ini karena pengaruh langsungnya tidak signifikan. Sementara pengaruh tidak langsungnya melalui Sikap terhadap Menyontek $\left(\mathrm{Y}_{1}\right)$ signifikan positif, meskipun hanya memberikan sumbangan yang sangat kecil (0,7 persen) untuk menerangkan variasinya. Hipotesis penelitian $4\left(\mathrm{H}_{4}\right)$ yang menyatakan: "Ada pengaruh yang positif dan signifikan Prokrastinasi Akademik $\left(\mathrm{X}_{2}\right)$ pada Perilaku Menyontek $\left(\mathrm{Y}_{2}\right)$, baik secara langsung maupun tidak langsung (melalui Sikap terhadap Menyontek $\left[\mathrm{Y}_{1}\right]$ )" tidak sepenuhnya dapat diterima. Hal ini karena pengaruh langsungnya tidak signifikan. 
Sementara pengaruh tidak langsungnya melalui Sikap terhadap Menyontek $\left(Y_{1}\right)$ signifikan, meskipun hanya memberikan sumbangan yang sangat kecil ( 0,2 persen) untuk menerangkan variasinya. Hipotesis penelitian $5\left(\mathrm{H}_{5}\right)$ yang menyatakan: "Ada pengaruh yang positif dan signifikan Sikap terhadap Menyontek $\left(\mathrm{Y}_{1}\right)$ pada Perilaku Menyontek $\left(\mathrm{Y}_{2}\right)$ ” diterima. Variabel ini memiliki pengaruh langsung, tetapi tidak memiliki pengaruh tidak langsung. Prokrastinasi Akademik $\left(\mathrm{Y}_{1}\right)$ dapat menerangkan 14,3 persen dari variansi Perilaku Menyontek $\left(\mathrm{Y}_{2}\right)$. Hal ini menunjukkan bahwa semakin positif Sikapnya terhadap Menyontek, Semakin tinggi tingkat Perilaku Menyonteknya.

\section{Pembahasan}

Pemaparan hasil penelitian sebagaimana dalam bagian tersebut di atas mengarahkan pada beberapa temuan pokok yang tidak sepenuhnya mendukung hipotesis yang telah dirumuskan sebelumnya. Sesuai dengan tahapan analisisnya, temuan tersebut dapat dijelaskan sebagai berikut:

\section{a. Pengarub Tingkat Keimanan dan Prokrastinasi Akademik pada Sikap terbadap Menyontek.}

Secara deskriptif Sikap terhadap Menyontek yang dimiliki oleh subjek (mahasiswa) bervariasi, dari sangat negatif (memandang bahwa perilaku menyontek merupakan perbuatan melanggar dan merugikan) sampai sangat positif (menyontek merupakan perbuatan yang wajar dan tidak melanggar). Namun demikian, secara umum rerata skor mereka mununjukkan bahwa sikap mereka cenderung netral, yakni sebagian besar dari mereka dapat menerima bahwa perilaku menyontek merupakan perbuatan yang wajar dan tidak melanggar.

Bervariasinya sikap mahasiswa ini menunjukkan bahwa sebagian kecil mahasiswa (yang memiliki skor pada ujung negatif pada rentang skala) berpandangan bahwa menyontek merupakan perbuatan yang merugikan dan melanggar. Sementara sebagian kecil yang lain berpandangan bahwa menyontek merupakan perbuatan yang wajar dan tidak melanggar. Perbedaan pandangan tersebut kemungkinan karena adanya perbedaan dalam cara memandang perilaku menyontek. Kelompok mahasiswa yang memiliki sikap positif cenderung memandang perilaku menyontek sebagai suatu kewajaran, bahkan mungkin sebagai suatu perbuatan yang tidak perlu dipermasalahkan. Konsekuensinya, mereka juga melakukan perilaku menyontek karena menurutnya itu adalah perbuatan yang wajar saja. Sedangkan kelompok mahasiswa yang memiliki sikap negatif cenderung mengaggap bahwa perilaku menyontek merupakan perbuatan yang melanggar dan merugikan. Karena itu, perilaku menyontek harus dihindari dan tidak selayaknya dilakukan. Konsekuensinya, kelompok tersebut cenderung menolak perilaku menyontek dan tidak mempraktikannya dalam proses pendidikan mereka.

Lebih lanjut, berdasarkan kelompoknya antara laki-laki dan perempuan cenderung sama sikapnya terhadap menyontek, yakni cenderung negatif. Hal ini karena rerata skor antara kelompok laki-laki dan perempuan cenderung negatif. Hal ini nampaknya lebih dikarenaan informasi yang mereka dapat bahwa perilaku menyontek merupakan perbuatan yang tidak 
benar dan melanggar. Konsekuensinya, mereka akan lebih menolak perilaku menyontek. Sikap seseorang merupakan evaluasi dalam diri terhadap suatu objek berdasarkan hasil belajar atau interksi yang dilakukan. Sehingga sikap tidak terlepas dari faktor-faktor yang memepengaruhinya, seperti norma agama yang diyakininya. Dalam ajaran Islam, menyontek termasuk perbuatan yang melanggar norma agama karena perilaku tersebut merupakan perbuatan yang tidak jujur. Konsekuensinya, mereka cenderung menolak perilaku menyontek yang mereka anggap tidak sesuai norma agama yang diyakininya. Sementara itu mereka yang tidak terlalu menyakini atas norma agamanya cenderung akan menerima perilaku menyontek.

Selain itu, perilaku menyontek yang erat kaitanya sengan evaluasi dalam proses pembelajaran juga tidak bisa dilepaskan dari perilaku mahasiswa yang suka menunda-nunda di dalam belajar maupun tugas-tugas akademiknya. Kebiasaan menunda-nunda tersebut menyebabkan mereka mengambil jalan pintas untuk menyontek, hal ini karena pada saat ujian tiba mereka tidak bisa menguasai meteri secara keseluruhan akibat menunda-nunda untuk belajar. Konsekuensinya, mereka yang suka menunda-nunda dalam belajar atau mengerjakan tugas akademik akan cenderung bersikap positif terhadap perilaku menyontek, karena keadaan mereka jika tidak menyontek tidak bisa mengerjakan soal dan akhirnya gagal. Sementara mereka yang tidak suka menunda-nunda belajar dan mengerjakan tugas akademik cenderung akan menolak perilaku menyontek karena mereka menganggap perbuatan itu hanya akan merugikan dan sia-sia.

Temuan berdasarkan data empiris sebagaimana disajikan dalam pembahasan sebelumnya tidak sepenuhnya mendukung hipotesis ketiga, yang menyatakan: "Ada pengaruh langsung Tingkat Keimanan pada Sikap terhadap Menyontek." Hasil analisis jalur terhadap data yang terkumpul memperlihatkan bahwa Tingkat Keimanan tidak memiliki pengaruh langsung yang signifikan pada Sikap mahasiswa terhadap Menyontek. Tidak berbeda dari temuan tersebut di atas, hasil analisis jalur juga menunjukkan bahwa pengaruh langsung Prokrastinasi Akademik pada Sikap terhadap Menyontek tidak signifikan.

Dengan demikian, dari variabel variabel independen, secara statistik maupun praktis tidak mempengaruhi variasi Sikap mahasiswa terhadap Menyontek. Kemungkinan lain, Sikap mahasiswa terhadap Menyontek dipengaruhi oleh faktor lain. Interaksi sosial yang dialami oleh mahasiswa juga dapat menentukan sikap mereka, situasi lembaga pendidikan serta kebudayaan turut menjadi pengaruh seseorang dalam bersikap.

Lebih lanjut, tidak signifikan pengaruh Keimanan pada Sikap terhadap Menyontek tersebut kemungkinan karena keimanan dipandang sebagai suatu yang privasi. Sebagaimana dibahas dalam kajian teori, keimanan memiliki komponen yang tak teramati karena bersifat mental/ psikologis (keyakinan). Disisi lain, dalam tingkatnya keimanan mahasiswa tersebut mungkin belum mencapai pada taraf ihsan. Secara hati dan lisan mereka mengimani, akan tetapi ketika dihadapkan pada permasalah yang kompleks atau bertentangan dengan keinaginan duniawinya, seperti menyikapi perilaku menyontek mereka masih toleran terhadap menyontek. Hal ini menunjukan bahwa sikap terhadap menyontek kemungkinan dipengaruhi oleh faktor-faktor lain yang lebih dominan seperti budaya atau kebiasaan yang umumnya dilakukan meskipun 
itu bertentangan dengan keyakinanan. Implikasi dari kemungkinan ini adalah bahwa dalam rangka memahami faktor-faktor Sikap terhadap Menyontek, penelitian di masa mendatang perlu mengkaitkan sikap tersebut dengan faktor lingkungan atau budaya disekitar mereka.

Tidak jauh berbeda dengan Keimanan, tidak signifikannya Prokrastinasi Akademik pada Sikap terhadap Menyontek kemungkinan disebabkan oleh faktor lain yang lebih dominan. Sebagimana diungkapkan dalam landasan teori bahwa sikap dipengaruhi oleh faktor internal dan eksternal, termasuk pengalaman pribadi individu yang berkaitan dengan perilaku menyontek. Mereka yang pernah menyontek tetapi tidak mendapatkan teguran serta sanksi tang tegas tidak akan jera untuk menyontek lagi. Selain itu kebiasaan yang umumnya sering terjadi dilingkungnya bahwa perilaku menyontek merupakan hal yang wajar juga dapat menumbuhkan sikap yang positif terhadap menyontek. Maka penelitin mendatang perlu mengaitkan sikap terhadap menyontek dengan faktor reward and punishment.

\section{b. Pengarub keimanan, Prokrastinasi Akademik, Sikap terhadap Menyontek pada Perilaku Menyontek}

Sebagaimana Sikap terhadap Menyontek, Perilaku Menyontek juga bervariasi, merentang dari sangat negatif (rendah) sampai sangat positif (tinggi). Meskipun demikian, perilaku menyontek mereka cenderung tinggi, karena nilai rerata variabel ini di atas rerata teoritis. Meskipun semua kelompok mahasiswa berdasarkan jenis kelamin di manapun mereka belajar cenderung tinggi perilaku menyonteknya, kelompok perempuan cenderung lebih negatif dari pada kelompok laki-laki.

Kecenderungan perilaku menyontek yang tinggi tersebut memberikan petunjuk bahwa secara umum mahasiswa sering berperilaku menyontek. Meskipun perilaku menyontek merupakan perbuatan yang melanggar, karena termasuk bentuk kecurangan akademik. Nampaknya sebagian besar mahasiswa tidak memperhartikannya, tetapi seperti menjadi sebuah kebiasaan dan menanggap wajar perbuatan tersebut. Lebih lanjut, kecenderungan penyebaran tingkat Perilaku Menyontek yang sangat variatif tersebut juga menunjukkan bahwa sebagian mahasiswa Muslim yang menjadi subjek penelitian ini telah melakukan praktik menyontek tersebut. Perilaku menyontek tersebut kemungkinan karena adanya penerimaan terhadap perilaku menyontek. Dalam kenyataannya, perilaku menyontek seolah hampir menjadi suatu kebiasaan, sehingga mereka memandang bahwa menyontek bukanlah perbuatan yang tabu lagi.

Apabila Perilaku Menyontek mahasiswa memang benar dipengaruhi oleh sikap, maka sikap mereka tidak dapat dilepaskan dari keyakinan dalam diri seseorang utamanya keyakinan dalam agamnya yang dianutnya. Mereka yang memiliki keyakinan bahwa ajarannya agama paling benar, memiliki Tingkat Keimanan yang tinggi. Sedangkan mereka yang meyakini ajaran agamanya kurang cenderung memiliki Tingkat Keimanan yang rendah. Berdasarkan cara pandang yang demikian ini maka diduga variasi subjek dalam variabel ini akan tercerminkan dalam variasi Sikap mereka pada Menyontek. Dengan kata lain, semakin tinggi Tingkat Keimanan mahasiswa, semakin negatif Sikap mereka terhadap Menyontek, dan sebaliknya. Demikian juga, semakin tinggi tingkat Prokrastinasi Akademik mereka, semakin positif Sikap mereka 
terhadap Menyontek, dan sebaliknya. Prokrastinasi Akademik dan sikap merupakan fenomena yang bertingkat (merentang dari yang sangat negatif sampai yang sangat positif), maka semakin positif Prokrastinasi Akademik, semakin positif Sikapnya terhadap Menyontek, dan sebaliknya.

Temuan berdasarkan data empiris sebagaimana disajikan dalam pembahasan sebelumnya tidak sepenuhnya mendukung hipotesis ketiga, yang menyatakan: "Ada pengaruh langsung maupun tidak langsung dengan Perilaku Menyontek." Hasil analisis jalur terhadap data yang terkumpul memperlihatkan bahwa Tingkat Keimanan tidak memiliki pengaruh langsung yang signifikan pada Perilaku Menyontek, tetapi memiliki pengaruh tidak langsung melalui Sikap terhadap Menyontek. Sedangkan pengaruh tidak langsungnya signifikan, sesuai yang yang dihipotesiskan. Meskipun demikian hipotesis tersebut tidak sepenuhnya dapat diterima. Hal ini karena pengaruh langsung pada Perilaku Menyontek secara empiris positif, tidak negatif sebagaimana yang dihipotesiskan. Meskipun pengaruh tidak langsung melalui Prokrastinasi Akademik secara statistik signifikan, secara praktis pengaruhnya tersebut tidak cukup bermakna karena hanya memberikan sumbangan yang sangat kecil ( 0,7 persen) untuk menjelaskaan varian Perilaku Menyontek. Untuk tujuan praktis, pengaruh yang demikian kecil tersebut dapat diabaikan. Dengan demikian, dapat dikatakan bahwa Tingkat Keimanan tidak memiliki pengaruh pada Perilaku Menyontek.

Tidak berbeda dari temuan tersebut di atas, hipotesis keempat (H4) yang menyatakan: "Ada pengaruh yang positif dan signifikan Prokrastinasi Akademik(X2) pada Perilaku Menyontek(Y2), baik secara langsung maupun tidak langsung (melalui Sikap terhadap Menyontek [Y1])” tidak sepenuhnya dapat diterima. Hal ini karena pengaruh langsung pada Perilaku Menyontek tidak signifikan. Sedangkan pengaruh tidak langsungnya signifikan, sesuai yang yang dihipotesiskan. Secara total, besarnya sumbangan Prokrastinasi Akademik, baik secara langsung maupun tidak langsung, pada varian Perilaku Menyontek adalah 0,2 persen. Besarnya sumbangan yang demikian kecil ini secara praktis tidak bermakna sehingga dapat diabaikan. Dengan kata lain Prokrastinasi Akademik, baik secara langsung maupun tidak langsung, tidak berpengaruh pada Perilaku Menyontek. Lebih lanjut, hasil analisis jalur juga menunjukkan pengaruh negatif yang sangat signfikan Sikap terhadap Menyontek pada Perilaku Menyontek. Hasil ini tidak sesuai dengan hipotesis yang diajukan, yang menyatakan: (H5) "Ada pengaruh yang positif dan signifikan Sikap terhadap Menyontek pada Perilaku Menyontek.” Meskipun Sikap tersebut memberikan sumbangan efektif sebesar 14,3 persen dari varian Perilaku Menyontek.

Dengan demikian, dari ketiga variabel independen, secara statistik maupun praktis tidak ada yang mempengaruhi variasi Perilaku Menyontek. Variasi Perilaku Menyontek mahasiswa tidak terefleksikan secara konsisten pada variasi Sikap mereka terhadap Menyontek. Temuan-temuan tersebut memberikan petunjuk bahwa variasi Perilaku Menyontek lebih dominan dipengaruhi oleh faktor lain. Meskipun secara empiris sebagaimana analisis dskriptif bahwa sikap mereka terhadap menyontek cenderung rendah tapi tidak secara konsisten diikuti oleh perilaku mereka dalam menyontek. Hal ini diduga ada factor lain yang mempengaruhi perilaku menyontek yang mereka lakukan seperti budaya. 
Kemungkinan lain, keinginan untuk memperoleh nilai yang tinggi serta tidak mengalami kegagalan saat ujian dapat menyebabkan seseorang megambil keputusan untuk melakukan perilaku menyontek. Hal ini sejalan dengan temuan Eric M. Andermen dan Tamera Murdock (2007) menunjukan beberapa alasan mahasiswa menyontek juga alasan ingin mendapatkan nilai yang tinggi. Selain itu, peraturan serta sanksi yang jelas atas perilaku menyontek yang selama ini dilakukan belum terlaksanakan dengan baik. Kemungkinan karena anggapan yang demikian inilah, banyak dijumpai perilaku menyontek di kalangan mahasiswa. Studi yang dilakukan oleh Peterson dan Seligmen (2004) menyatakan bahwa menyontek terjadi karena dosen membiarkan mahasiswa serta tidak mengawasi dengan baik.

Variasi perilaku menyontek mahasiswa tersebut kemungkinan juga dipengaruhi oleh perbedaan self-effcacy (keyakinan diri) seseorang, yaitu keyakinan tentang kemampuan dirinya dalam bertindak. Di antara para ahli yang menyatakan hal tersebut adalah Andermen dan Murdock (2007). Rendahnya keyakinan diri yang dimiliki mahasiswa dapat menyebabkan mahasiswa tersebut menyontek. Sementara itu praktik menyontek yang telah berlangsung selami ini tidak mendapatkan sangsi yang tegas. Karena perilaku menyontek oleh mahasiswa tidak dapat dipisahkan dari alasan-alasan tersebut, konsekuensinya, mahasiswa yang terpengaruh oleh mahasiswa lain yang juga menyontek karena merasa tidak ada hukuman yang diterima jika mereka menyontek sedang mereka bisa memperoleh nilai yang tinggi.

Temuan ini memberikan petunjuk tidak adanya konsistensi antara fenomena psikologis yang tidak teramati secara langsung dengan fenomena perilaku yang teramati. Hal ini dapat terjadi karena terdapat pengaruh lain yang lebih kuat pada Perilaku Menyontek sehingga ketiga variabel tersebut tidak terlalu memberi pengaruh yang berarti pada keputusannya untuk menyontek. Lebih dari itu, temuan ini juga menunjukkan bahwa perilaku subjek (mahasiswa Muslim) tidak tergantung pada faktor psikologis yang relevan. Hal ini karena sikap seseorang tentang objek, tidak mendorongnya untuk berperilaku sebagaimana apa yang diyakininya tentang objek tersebut.

Dengan demikian dapat disimpulkan bahwa kedua variabel pertama tersebut memiliki pola yang berbeda dalam mempengaruhi respon tersebut. Tingkat Keimanan dan Prokrastinasi Akademik berpengaruh pada Perilaku Menyontek secara tidak langsung melalui Sikap terhadap Menyontek. Sedangkan pengaruh Sikap terhadap Menyontek pada Perilaku Menyontek tidak berpengaruh. Ketiga variabel yang terkait tersebut tidak terlepas dari konsep Sikap, yakni bagaimana menilai perilaku menyontek tersebut menurut anggapannya. Mahasiswa yang berpandangan bahwa menyontek merupakan perbuatan yang melanggar dan merugikan, akan memiliki sikap yang negatif pada perilaku menyontek. Sikap negatif ini yang akan menimbulkan keyakinan, perasaan, maupun kecenderungan bertindaknya sehingga ia tidak akan berperilaku menyontek. Sebaliknya, mahasiswa yang berpandangan menyontek merupakan perbuatan yang tidak melanggar dan wajar saja akan memiliki sikap yang positif terhadap perilaku menyontek. Sikap positif ini yang akan mempengaruhi keyakinan, perasaan, maupun kecenderungan bertindaknya sehingga ia akan berperilaku menyontek. 
Penjelasan tersebut juga memberikan petunjuk bahwa variabel-variabel tersebut tidak semata-mata berisi aspek psikologis, tetapi juga aspek sosial. Hal ini memberikan implikasi bahwa penelitian yang akan datang perlu memasukkan aspek sosial yang berhubungan dengan perilaku menyontek sebagai faktor yang diuji pengaruhnya pada sikap maupun perilaku menyontek. Dengan penelitian yang demikian ini, penejelasan tentang fenomena tentang perilaku Menyontek akan semakin akurat.

\section{F. Kesimpulan Dan Rekomendasi}

Hasil analisis jalur menunjukan bahwa tidak semua hipotesis yang diajukan dapat diterima sepenuhnya secara empiris. Pertama, Tingkat Keimanan $\left(\mathrm{X}_{1}\right)$ secara empiris tidak memiliki pengaruh negatif yang signifikan pada Sikap terhadap Menyontek $\left(\mathrm{Y}_{1}\right)$. Begitu juga Prokrastinasi Akademik $\left(\mathrm{X}_{2}\right)$ secara empiris tidak memiliki pengaruh yang positif yang signifikan pada Sikap terhadap Menyontek. Oleh karena itu, hipotesis $1\left(\mathrm{H}_{1}\right)$ dan hipotesis $2\left(\mathrm{H}_{2}\right)$ tidak diterima. Kedua variabel independen/eksogenus ini tidak memiliki pengaruh secara langsung pada Sikap terhdap Menyotek. Kedua, Pengaruh Keimanan $\left(\mathrm{X}_{1}\right)$ dan Prokrastinasi Akademik $\left(\mathrm{X}_{2}\right)$ dan Sikap terhadap Menyontek $\left(\mathrm{Y}_{1}\right)$ pada Perilaku Menyontek $\left(\mathrm{Y}_{2}\right)$ secara empiris tidak selalu mendukung hipotesis. Keimanan $\left(\mathrm{X}_{1}\right)$ tidak memiliki pengaruh langsung yang signifikan tetapi memiliki pengaruh tidak langsung (melalui Sikap terhadap Menyontek $\left[\mathrm{Y}_{1}\right]$ ) yang signifikan pada Perilaku Menyontek $\left(\mathrm{Y}_{2}\right)$. Hal ini berarti bahwa Hipotesis $3\left(\mathrm{H}_{3}\right)$ tidak dapat diterima sepenuhnya. Lebih lanjut, meskipun memiliki pengaruh secara tidak langsung yang signifikan, sumbangan efektif Keimanan $\left(\mathrm{X}_{1}\right)$ sangat kecil (hanya 0,7 persen) sehingga secara praktis kurang bermakna untuk menjelaskan variasi Perilaku Menyontek $\left(\mathrm{Y}_{2}\right)$. Prokrastinasi Akademik $\left(\mathrm{X}_{2}\right)$ tidak memiliki pengaruh yang signifikan secara langsung pada Perilaku Menyontek $\left(\mathrm{Y}_{2}\right)$. Tetapi memiliki pengaruh tidak langsung (melalui Sikap terhadap Menyontek $\left[\mathrm{Y}_{1}\right]$ ) yang signifikan pada Perilaku Menyontek $\left(\mathrm{Y}_{2}\right)$. Dengan demikian, hipotesis $4\left(\mathrm{H}_{4}\right)$ tidak dapat diterima sepenuhnya. Namun demikian, sumbangan Prokrastinasi Akademik $\left(\mathrm{X}_{2}\right)$ sangat kecil (0,2 persen) untuk menerangkan variasi Perilaku Menyontek $\left(\mathrm{Y}_{2}\right)$. Karena itu, secara praktis pengaruh tersebut kurang bermakna. Sikap terhadap Menyontek $\left(\mathrm{Y}_{1}\right)$ memiliki pengaruh yang negatif signifikan pada Perilaku Menyontek $\left(\mathrm{Y}_{2}\right)$. Hanya saja, pengaruh langsung tersebut tidak seperti yang dihipotesiskan karena pengaruhnya positif. Dengan demikian hipotesis $5\left(\mathrm{H}_{5}\right)$ tidak dapat diterima. Namun demikian, sumbangan Sikap terhadap Menyotek (Y1) cukup besar (14,3 persen) untuk menerangkan variasi Perilaku Menyontek (Y2). Akan tetapi pengaruh itu tidak bermakna karena bertentangan dengan hipotesis yang diajukan.

Dengan demikian, hanya variabel Keimanan dan Prokrastinasi Akademik secara tidak langsung (melalui Sikap terhadap Menyontek $\left[\mathrm{Y}_{1}\right]$ ) memiliki pengaruh yang signifikan pada Perilaku Menyontek $\left(\mathrm{Y}_{2}\right)$. Kedua variabel tersebut secara total menyumbangkan 0,9 persen pada varian Perilaku Menyontek $\left(\mathrm{Y}_{2}\right)$. Namun demikian, sumbangan Keimanan $\left(\mathrm{X}_{1}\right)$ dan Prokrastinasi Akademik $\left(\mathrm{X}_{2}\right)$ sangat kecil (0,9 persen) untuk menerangkan variasi Perilaku Menyontek $\left(\mathrm{Y}_{2}\right)$. Karena itu, secara praktis pengaruh tersebut kurang bermakna. Dengan demikian ketiga variabel tersebut, Keimanan, Prokrastinasdi dan Sikap terhadap Menyontek terhadap perilaku 
menyontek bukanlah faktor yang paling menentukan seseorang tersebut berperilaku menyontek. Akan tetapi terdapat faktor lain yang diluar model yang mempengaruhinya.

\section{Bibiliografi}

Al-Wazat, Abdullah \& Ahmad Salamah, dkk. 1994, Pokok-Pokok Keimanan, Tarmana Ahmad Qasim, Bandung: Trigenda Karya.

Ancok, Djamaluddin dan Fuad Nashori Suroso, 1994, Psikologi Islam, Yogyakarta: Pustaka Pelajar.

Azwar, Saifuddin, 2007, Sikap Manusia, Yogyakarta: Pustaka Pelajar.

Cronbach, Lee J., 1951, "Coeficient Alpha and the Internal Structure of Test," Psychometrika, 16.

Daradjat, Zakiyah, 1993, Ilmu Jiwa Agama, Jakarta: Bulan Bintang.

Departemen Pendidikan dan Kebudayaan, 2008, Kamus Besar Bahasa Indonesia, Jakarta: Balai pustaka.

Eisenberg, Jacob, 2004, To Cheat Or Not To Cheat: Effects OfMoral Perspective And Situational Variables On Students' Attitudes, Journal of Moral Education, Vol. 33, No. 2, June 2004, University College Dublin, Ireland.

Fishbein, M., \& Ajzen, I., 1975, Belief, Attitude, Intention, and Behavior: An Introduction to Theory and Research, Reading, MA: Addison-Wesley.

Ghufron, M. N., 2003. Hubungan Kontrol Diri dan Persepsi Remaja terhadap Penerapan Disiplin Orang Tua dengan Prokrastinasi Akademik, Thesis. Jogjakarta: Program Pasca Sarjana Universitas Gadjah Mada Yogyakarta. Diakases 11 Januari 2013 dari http: //www. damandiri.or.id/file/mnurgufronugmbab2.pdf

Ghufron, Nur \& Rini Risnawita, 2011, Teori-Teori Psikologi, Jogjakarta: Ar-Ruzz Media.

Hartanto, Dody, 2012, Bimbingan \& Konseling Menyontek: Mengungkap Akar Masalah dan Solusinya, Jakarta: Indeks.

Maududi, Abul A’la, 1975, Prinsip-prinsip Islam (Principles of Islam), Terj. Abdullah Suhalili, Bandung: Al-Ma'arif.

Mueller, Daniel J., 1986, Measuring Social Attitudes: A Handbook for Researchers and Practitioners, New York: Teachers College Press. 
Pedhazur, Elazar P., 1982, Multiple Regression in Behavioral Research: Explanation and Prediction, New York: CBS College.

Rumiani, 2006, Prokrastinasi Akademik Ditinjau Dari Motivasi Berprestasi dan Stres Mahasiswa, Jurnal Psikologi Universitas Diponegoro Vol.3 No. 2, Desember 2006

Sabiq, Syid, tt, Inilah Islam, Semarang: CV. Toha Putra

Tim Redaksi KBBI Pusat Bahasa, 2008, Kamus Besar Bahasa Indonesia Pusat Bahasa, Edisi keempat, Jakarta: Gramedia.

Zuardi, Trisno, 2011, Pencegahan dan Penanggulangan Plagiat Di Perguruan Tinggi, Kementrian Pendidikan Nasional Biro Kepegawaian

Zuhdi, Masjfuk, 1988, Studi Islam Jilid I: Akidah, Jakarta: Rajawali. 